\title{
PENGEMBANGAN BAHAN AJAR BERBANTUAN ADVANCE ORGANIZER UNTUK MENINGKATKAN PENGUASAAN KONSEP PESERTA DIDIK PADA MATERI SUHU DAN KALOR
}

\author{
Selly Wahyuni ${ }^{1}$, Wahyudi'), ( Wayan Gunada') \\ 1)Pendidikan Fisika, Fakultas Keguruan dan Ilmu Pendidikan, Universitas Mataram, Nusa Tenggara Barat, Indonesia \\ Corresponding author : Selly Wahyuni \\ E-mail : sellyusuf26@gmail.com
}

Diterima 07 Januari 2021, Direvisi 23 Maret 2021, Disetujui 24 Maret 2021

\begin{abstract}
ABSTRAK
Penelitian pengembangan ini bertujuan untuk menghasilkan produk bahan ajar berupa modul berbantuan model pembelajaran advance organizer yang valid, praktis dan efektif untuk meningkatkan penguasaan konsep peserta didik pada materi suhu dan kalor. Desain penelitian yang digunakan adalah model 4D yang terdiri dari define, design, develop dan disseminate. Produk yang dikembangkan berupa Rencana Pelaksanaan Pembelajaran (RPP), Modul Ajar Berbantuan model Advance Organizer, dan instrumen tes berupa soal penguasaan konsep. Teknik pengumpulan data menggunakan lembar validasi, soal dan angket respon peserta didik. Data validitas dianalisis dengan analisis validasi ahli untuk menentukan nilai validitas perangkat. Peningkatan penguasaan konsep fisika dianalisis dengan menentukan standar gain dari hasil sebelum dan sesudah pembelajaran. Validitas Rencana Pelaksanaan Pembelajaran (RPP) sebesar 84,72\%, Modul Ajar Berbantuan model Advance Organizer sebesar $82,07 \%$ dan soal penguasaan konsep sebesar $76,85 \%$. Reliabilitas RPP, modul ajar dan soal tes penguasaan konsep di atas $75 \%$ yang menunjukkan keseluruhan aspek yang dinilai termasuk dalam kategori reliabel. Modul juga efektif untuk meningkatkan penguasaan konsep fisika. Diperoleh $\mathrm{N}$-gain sebesar 0,43 dengan kategori sedang. Berdasarkan hasil tersebut dapat disimpulkan bahwa bahan ajar yang dikembangkan valid, praktis serta efektif digunakan untuk meningkatkan penguasaan konsep peserta didik.
\end{abstract}

Kata kunci: bahan ajar; advance organizer, suhu dan kalor; penguasaan konsep

\begin{abstract}
This development research aims to produce teaching material products in the form of modules assisted by advanced organizer learning models that are valid, practical and effective to improve students' mastery of concepts on temperature and heat material. The research design used is the 4D model which consists of define, design, develop and disseminate. Products developed in the form of a Learning Implementation Plan (RPP), Assisted Teaching Module with the Advance Organizer model, and test instruments in the form of concept mastery questions. Data collection techniques used validation sheets, questions and student response questionnaires. The validity data were analyzed by using expert validation analysis to determine the validity value of the device. The increase in mastery of physics concepts was analyzed by determining the standard gain from the results before and after learning. The validity of the Learning Implementation Plan (RPP) was $84.72 \%$, the Assisted Teaching Module with the Advance Organizer model was $82,07 \%$ and the conceptual mastery questions were $76,85 \%$. The reliability of RPP, teaching modules and concept mastery test questions were above $75 \%$ which showed that all aspects assessed were included in the reliable category. Modules are also effective for improving mastery of physics concepts. Obtained $\mathrm{N}$-gain of 0,43 in the medium category. Based on these results it can be concluded that the teaching materials developed are valid, practical and effective to be used to improve students' mastery of concepts
\end{abstract}

Keywords: teaching material; advance organizer; temperature and heat; concept mastery.

\section{PENDAHULUAN}

Sains merupakan ilmu pengetahuan yang mempelajari tentang sebab-akibat fenomena yang terjadi di alam. Sains dapat dipelajari sebagai kumpulan pengetahuan yang menelaah atau mengkaji fakta-fakta empiris.
Hakikat sains mencakup proses, produk, dan sikap. Salah satu cabang sains adalah fisika. Fisika didefinisikan sebagai salah satu cabang ilmu pengetahuan alam dasar yang penting untuk dipelajari. Fisika memiliki karakter sebagai proses, produk dan sikap. Sains 
sebagai proses menguatamakan pada bagiaman cara mendapatkan ilmu pegetahuan. Sari et al (2016) menyatakan bahwa fisika sebagai produk merupakan kumpulankumpulan pengetahuan yang berupa fakta, konsep, generalisasi, prinsip, teori dan hukum fisika. Sementara itu, sains sebagai sikap lebih menekankan pada upaya membekali, melatih, atau menanamkan nilai-nilai positif dalam diri peserta didik (Gunawan, 2017).

Materi dalam fisika cukup kompleks. Dalam artian bahwa materi yang disajikan terdiri dari komponen-komponen yang saling berkaitan satu sama lain. Inilah yang menjadi momok menakutkan bagi peserta didik. Akhirnya di dalam mindset peserta didik tertanamkan bahwa mata pelajaran fisika adalah salah satu mata pelajaran yang sulit untuk dipelajari sehingga menyebabkan hasil belajar peserta didik pada mata pelajaran ini cukup rendah. Hasil belajar yang rendah ini menunjukkan bahwa penguasaan konsep fisika rendah, artinya peserta didik belum mampu untuk memahami, mengingat serta menerapkan konsep tersebut dalam kehidupan sehari-hari. Hidayat (2019) menyatakan bahwa penguasaaan konsep adalah kemampuan peserta didik untuk memahami makna yang dapat diungkapkan kembali dalam bentuk teori serta dapat diterapkan dalam suatu proses penyelesaian masalah. Lebih lanjut, penguasaan konsep adalah kemampuan peserta didik dalam memahami makna ilmiah suatu konsep setelah pembelajaran berlangsung untuk dapat diterapkan dalam kehidupan sehari-hari.

Penguasaan konsep peserta didik dapat digunakan dalam menjelaskan suatu fenomena yang mereka lihat pada lingkungan. Semakin tinggi penguasaan konsep yang dimiliki, maka semakin baik peserta didik dapat menjelaskan dan menyelesaikan permasalah yang dihadapi. Agar konsep yang telah dipelajari dapat diingat dalam jangka waktu yang lama, maka diperlukan pembelajaran yang bermakna. Harjono (2012) menyatakan pembelajaran bermakna (meaningful learning) lebih menekankan pada pentingnya pemahaman konsep serta hubungan antar konsep-konsep. Belajar bermakna menurut Ausubel adalah belajar yang disertai pengertian. Belajar bermakna akan terjadi apabila informasi baru yang diterima oleh peserta didik berkaitan dengan informasi (pengetahuan awal) yang telah mereka miliki sebelumnya.

Kemampuan awal yang dimiliki oleh peserta didik juga tidak diperhatikan. Tuntutan yang diberikan kepada guru agar mampu membawa semua peserta didik mencapai target ketuntasan materi sedangkan waktu belajar tatap muka di dalam kelas terbatas. Sehingga, fokus kegiatan belajar mengajar seringkali didominasi oleh penyampaian informasi sebanyak-banyaknya tanpa memberikan kesempatan pada peserta didik untuk mengkonstruksi pengetahuannya. Hal ini akan mempengaruhi bagaimana mereka dapat menerima pengetahuan baru yang diajarkan untuk disimpan di dalam struktur kognitif.

Advance Organizer merupakan sarana membantu peserta didik membuat informasi menjadi bermakna. Model pembelajaran Advance Organizer adalah suatu kerangka konseptual yang menyajikan bagian-bagian utama atau konsep-konsep pokok dari materi yang harus dipelajari yang dihubungkan dengan struktur kognitif sehingga pengetahuan baru nantinya akan tertanam kuat dan mengakibatkan belajar menjadi bermakna. Seseorang memperoleh pengetahuan mengenai konsep, prinsip, dan ide atau gagasan melalui melalui penerimaan bukan melalui penemuan (Suprijono, 2016). Lebih lanjut, Harjono (2018) menyatakan bahwa cara paling efektif yang dapat digunakan untuk menghubungkan materi yang telah dipelajari dengan materi yang telah tersimpan dalam struktur kognitif atau konsep lama yang telah ada dengan konsep baru adalah dengan memanfaatkan Advance Organizer.

Di tengah pandemic Covid-19 yang melanda seluruh dunia, sektor pendidikan juga terkena imbasnya. Pembelajaran tatap muka di sekolah terpaksa ditiadakan, diganti dengan pembelajaran secara daring (dalam jaringan) melalui berbagai aplikasi yang ada. Akibatnya peserta didik belajar secara mandiri dari rumahnya masing-masing. Namun di sekolah tempat dilakukan penelitian telah menerapkan pembelajaran tatap muka namun waktu belajar yang terpaksa dikurangi. Akibatnya pembelajaran di kelas kurang efektif dan mengakibatkan peserta didik lebih banyak belajar secara mandiri di rumah. Hal ini menyebabkan peserta didik kesulitan dalam belajar serta memahami materi, termasuk materi suhu dan kalor.

Pembelajaran materi suhu dan kalor ini perlu melibatkan peserta didik secara aktif untuk menggali informasi dari pengalaman dan diskusi guna meningkatkan pemahaman materi peserta didik. Banyak aplikasi dalam kehidupan sehari-hari yang dapat digali dari materi ini sehingga peserta didik akan lebih mudah mengidentifikasi dan membentuk pengetahuan dari peristiwa yang dialaminya sehari-hari. Materi ini juga dapat disajikan dalam berbagai metode dan strategi, terutama dikemas dalam kegiatan laboratorium. 
Oleh sebab itu, peneliti menawarkan salah satu alternatif pembelajaran yang bisa diterapkan yaitu dengan mengembangkan bahan ajar fisika dalam hal ini berupa modul berbantuan Advance Organizer (AO). Prastowo (2012), menyatakan bahwa bahan ajar adalah segala bahan (baik informasi, alat, maupun teks) yang disusun secara sistematis, yang menampilkan sosok utuh dari kompetensi yang akan dikasai peserta didik dan digunakan dalam proses pembelajaran dengan tujuan perencanaan dan penelaahan implementasi pembelajaran. Modul merupakan suatu bahan ajar yang disusun secara sistematis menggunakan bahasa yang mudah dipahami dengan tujuan peserta didik dapat belajar secara mandiri tanpa ataupun dengan bimbingan guru. Lebih lanjut, Syamsudin (2005) menyatakan bahwa modul merupakan bahan ajar cetak yang dirancang untuk dapat dipelajari secara mandiri oleh peserta didik. Modul disebut juga media untuk belajar mandiri karena di dalamnya dilengkapi dengan petunjuk untuk belajar sendiri.

$$
\text { Modul digunakan sebagai }
$$

pengorganisasian materi pembelajaran yang memperlihatkan fungsi pendidikan. Strategi pengorganisasian materi pembelajaran mengacu pada upaya untuk menunjukkan kepada peserta didik keterkaitan antara fakta, konsep, prosedur dan prinsip yang terkandung pada materi pembelajaran. Strategi pengorganisasian materi pembelajaran terdiri dari tiga tahapan proses berpikir, yaitu pembentukan konsep, interpretasi konsep, dan aplikasi prinsip. Strategi tersebut sangat penting dalam mendesain pembelajaran sehingga peserta didik akan lebih tertarik dalam belajar yang secara otomatis dapat meningkatkan hasil belajar (Herwati, 2013).

Adapun kriteria modul sesuai dengan pedoman penulisan modul yang dikeluarkan Direktorat Pendidikan Menengah Kejuruan, Direktorat Jenderal Pendidikan Dasar dan Menengah, Departemen Pendidikan Nasional Tahun 2003 (Lestari, 2013) yaitu: 1)Self Instructional, yaitu mampu membelajarkan peserta didik secara mandiri; 2)Self contained yaitu seluruh materi pembelajaran dari satu unit kompetensi atau sub kompetensi yang dipelajari terdapat di dalam satu modul secara utuh; 3)Stand alone yaitu modul dikembangkan tidak tergantung pada media lain atau tidak harus digunakan bersama-sama dengan media pembelajaran lain; 4)Adaptive, modul memiliki daya adaptif yang tinggi terhadap perkembangan ilmu dan teknologi; dan 5)User friendly yakni modul hendaknya bersahabat dengan pemakainya.
Modul yang dikembangkan berbantuan model pembelajaran $A O$. $A O$ atau dikenal dengan pengaturan awal mengarahkan peserta didik ke materi yang akan dipelajari dan menolong mereka untuk mengingat kembali informasi yang berhubungan dengan materi tersebut sehingga dapat membantu peserta didik untuk menanamkan pengetahuan baru. Diharapkan, dengan adanya pengembangan modul berbantuan $A O$ dapat meningkatkan penguasaan konsep peserta didik terutama dalam materi suhu dan kalor.

\section{METODE PENELITIAN \\ Jenis Penelitian}

Penelitian ini menggunakan metode penelitian dan pengembangan atau Research and Development (R\&D). Model pengembangan $4 D$ yang terdiri atas 4 tahapan yaitu: (1) Define (pendefinisian); (2) Desain (perancangan); (3) Develop (pengembangan); (4) Desseminate (penyebarluasan). Metode penelitian dan pengembangan adalah metode penelitian yang digunakan untuk menghasilkan produk tertentu, dan menguji keefektifan produk tersebut (Sugiyono, 2014:407). Hasil akhir dari penelitian ini berupa produk modul ajar berbantuan model pembelajaran advance organizer. Subjek dalam penelitian ini adalah peserta didik kelas XI IPA Tahun Ajaran 2020/2021 MA Hikmatusysyarif NW Salut, Narmada yang berjumlah 25 orang.

\section{Instrumen Penelitian}

Instrumen penelitian adalah suatu alat yang digunakan untuk mengumpulkan data dan mengukur fenomena yang diamati (Sugiyono, 2012). Instrumen dalam penelitian pengembangan ini terdiri atas perangkat pembelajaran fisika berupa modul ajar, RPP dan soal tes penguasaan konsep. Sementara itu untuk instrumen pengumpulan data berupa angket untuk mengukur validitas, praktis, dan keefektifan perangkat.

\section{Teknik Analisis Data}

Analisis Validitas Perangkat Pembelajaran

Analisis validasi ahli dilakukan dengan cara:

$$
\text { Validitas }(V)=\frac{\text { Total skor validasi }}{\text { Total skor maksimal }} \times 100 \%
$$

Hasil validitas yang telah diketahui persentasenya dapat dicocokkan dengan kriteria validitas seperti yang disajikan pada Tabel 1.

Tabel 1. Kriteria Validitas Perangkat Pembelajaran

\begin{tabular}{cc}
\hline Skor & Kriteria \\
\hline $85,01-100,00 \%$ & Sangat valid \\
$70,01-85,00 \%$ & Cukup Valid \\
$50,01-70,00 \%$ & Kurang valid \\
\hline
\end{tabular}




\section{$01,00-50,00 \%$ \\ Tidak valid
(Akbar, 2013).}

Analisis Kepraktisan Perangkat Pembelajaran

Analisis keterlaksanaan (kepraktisan)

kegiatan pembelajaran digunakan untuk melihat apakah semua kegiatan dapat terlaksana serta keruntutan dalam pembelajaran. Analisis dapat dihitung dengan persamaan:

persentase ketercapaian $=\frac{\text { skor perolehan }}{\text { skor } \text { masksimal }} \times 100 \%$

Selanjutnya mengkonversi skor rata-rata yang dieproleh ke dalam tabel konversi skala 4.

Tabel 2. Interprestasi Skor Keterlaksanaan Pembelajaran

\begin{tabular}{ll}
\hline \multicolumn{1}{c}{ Presentase } & \multicolumn{1}{c}{ Klasifikasi } \\
\hline $81,26 \%-100 \%$ & Sangat baik \\
$62,60 \%-81,25 \%$ & Baik \\
$43,80 \%-62,50 \%$ & Kurang Baik \\
$25,00 \%-43,70 \%$ & Tidak Baik \\
\hline
\end{tabular}

(Setyawati, 2017)

\section{Analisis Keefektifan Perangkat Pembelajaran}

Analisis keefektifan bahan ajar didasarkan pada penilaian peserta didik dalam menyelesaikan tes hasil belajar dalam hal ini penguasaan konsep. Peningkatan penguasaan konsep dapat ditentukan dengan menggunakan standar gain dengan persamaan berikut:

Keterangan:

$$
\text { Std }<g>=\frac{\bar{X}_{\text {sesudah }}-\bar{X}_{\text {sebelum }}}{\bar{X}_{\text {maks }-}-\bar{X}_{\text {sebelum }}}
$$

$\bar{X}_{\text {sebelum }}:$ skor pre-test

$\bar{X}_{\text {sesudah }}:$ skor post-test

$\bar{X}_{\text {maks }}:$ : skor maksimum 100

Berdasarkan hasil yang diperoleh
dengan menggunakan standar gain,
dikelompokkan kategori peserta didik dikelompokkan kategori
berdasarkan Tabel 3 berikut.

Tabel 3. Interpretasi Indeks N-Gain

\begin{tabular}{c|c}
\hline $\mathbf{N}$-Gain Skor (g) & Interpretasi \\
$0,70<\mathrm{g}<1,00$ & Tinggi \\
$0,30<\mathrm{g}<0,70$ & Sedang \\
$0,00<\mathrm{g}<0,30$ & Rendah \\
\hline & (Sundayana, 2014).
\end{tabular}

Analisis Reliabilitas Perangkat Pembelajaran

Reliabilitas dalam penelitian ini menggunakan metode Borich yang dikenal dengan Percentage Agreement (PA) yaitu persentase kesepakatan antar penilai yang merupakan suatu persentase kesesuaian nilai antara penilai pertama dengan penilai kedua. Instrumen dikatakan reliabel jika nilai presentase kesepakatannya lebih atau sama dengan $75 \%$ (Borich, 1994).

Percentage Agreement (PA) dapat dirumuskan:

Keterangan:

$$
\mathrm{PA}=\left(1-\frac{\mathrm{A}-\mathrm{B}}{\mathrm{A}+\mathrm{B}}\right) 100 \%
$$

PA : Reliabilitas instrumen (percentage of agreetment)

A : skor penilai yang lebih besar

B : skor penilai yang lebih kecil

\section{HASIL DAN PEMBAHASAN \\ Tahap Pendefinisian (Define)}

Tahap define merupakan tahap awal yang bertujuan untuk mendapatkan informasi tentang karakteristik peserta didik, permasalahan yang muncul saat pembelajaran berlangsung, metode pembelajaran yang digunakan oleh guru dan media penunjang lainnya serta mengkaji kurikulum yang digunakan. Tahap define pada penelitian ini meliputi analisis awal yang bertujuan untuk menetapkan masalah dasar yang dihadapi dalam pembelajaran fisika di SMA meliputi kurikulum dan permasalahan lapangan sehingga dibutuhkan pengembangan perangkat pembelajaran, analisis peserta didik meliputi kemampuan hasil belajar dalam hal ini penguasaan konsep, analisis tugas berupa isi materi ajar secara garis besar yakni pada materi suhu dan kalor, analisis konsep, serta perumusan tujuan pembelajaran.

\section{Tahap Perancangan (Design)}

Tahap design bertujuan untuk merancang perangkat pembelajaran dan instrumen penelitian. Pada tahap ini perangkat pembelajaran yang disusun meliputi RPP, Modul Ajar dan instrumen tes penguasaan konsep. Adapun instrumen penelitian yang digunakan adalah lembar validasi ahli, angket respon peserta didik serta soal tes untuk mengetahui peningkatan hasil belajar fisika berupa penguasaan konsep.

Rancangan awal yang selanjutnya dikembangkan menggunakan pendekatan saintifik berbantuan model pembelajaran advance organizer. RPP yang disusun untuk draft awal adalah tiga pertemuan untuk materi suhu dan kalor. Modul ajar yang dikembangkan mengacu paa konsep suhu dan energi yang ada dalam buku pelajaran SMA. Modul ajar berbantuan ao yang dikembangkan terdiri dari tiga pertemuan, yang tiap pertemuan yang disusun dalam modul mengikuti sintak dari model pembelajaran ao yakni adanya kegiatan pendahuluan, kegiatan inti dan terakhir kegiatan penutup. Adapun draft modul yang digunakan dalam penelitian ini terdiri dari cover, halaman awal (judul, kata pengantar, dan daftar isi), petunjuk penggunaan modul, silabus 
pembelajaran, peta konsep, kegiatan belajar, latihan atau tugas serta halaman akhir yang teridiri dari dari daftar pustaka, kunci jawaban dan glosarium.

Tahapan ini juga menghasilkan perumusan indikator dan tujuan pembelajaran berdasarkan analisa konsep dan tugas. Selanjutnya indikator ini digunakan untuk menyusun instrumen tes penguasaan konsep.

Adapun sintak model pembelajaran Advance Organizer dapat dilihat pada tabel 4.

Tabel 4. Sintak Model Pembelajaran AO

\begin{tabular}{|c|c|}
\hline Tahap & Tingkah laku guru \\
\hline $\begin{array}{l}\text { Tahap } 1 \\
\text { Menjelaskan panduan } \\
\text { pembelajaran/penyajian } \\
\text { Advance Organizer }\end{array}$ & $\begin{array}{l}\text { Menjelaskan tujuan } \\
\text { pembelajaran } \\
\text { Mempresentasikan } \\
\text { panduan } \\
\text { pembelajaran } \\
\text { Advance Organizer } \\
\text { Menumbuhkan } \\
\text { kesadaran } \\
\text { pengetahuan dan } \\
\text { pengalaman peserta } \\
\text { didik yang relevan }\end{array}$ \\
\hline $\begin{array}{l}\text { Tahap-2 } \\
\text { Menjelaskan materi } \\
\text { dan tugas-tugas } \\
\text { pembelajaran }\end{array}$ & $\begin{array}{l}\text { Menjelaskan materi } \\
\text { pembelajaran } \\
\text { Membangkitkan } \\
\text { perhatian peserta } \\
\text { didik } \\
\text { Mengatur secara } \\
\text { eksplisit tugas-tugas } \\
\text { Menyusun }\end{array}$ \\
\hline & $\begin{array}{ll}\text { susunan logis } & \text { logaran } \\
\text { materi pembelajaran }\end{array}$ \\
\hline $\begin{array}{l}\text { Tahap-3 } \\
\text { Memperkokoh } \\
\text { pengorganisasi kognitif }\end{array}$ & $\begin{array}{l}\text { Menggunakan } \\
\text { prinsip-prinsip } \\
\text { secara } \\
\text { Terintegrasi kritis } \\
\text { guna memperjelas } \\
\text { materi pembelajaran } \\
\text { Meningkatkan } \\
\text { keaktifan aktivitas } \\
\text { pembelajaran } \\
\text { Mengembangkan } \\
\text { pendekatan- } \\
\text { pendekatan }\end{array}$ \\
\hline
\end{tabular}

\section{Tahap Pengembangan (Develop)}

Tahap pengembangan merupakan tahapan realisasi rancangan produk perangkat pembelajaran yang akan digunakan. Tahap pengembangan (develop) merupakan tahap untuk menghasilkan produk pengembangan yang dinilai oleh validator ahli, revisi produk yang telah dikembangkan sebelum dilakukan uji coba terbatas. Validasi dilakukan oleh 6 orang yang terdiri dari 3 orang dosen Fisika sebagai validator ahli dan 3 orang guru mata pelajaran fisika sebagai validator prakisi. Validasi bertujuan agar produk yang telah dikembangkan layak untuk ujicoba. Selanjutnya perbaikan pada produk berdasarkan komentar dan saran dari validator.

Langkah berikutnya yakni melakukan ujicoba lapangan secara terbatas di kelas XI IPA MA Hikmatsysyarif NW Salut, Narmada. Ujicoba ini melibatkan 25 orang peserta didik, satu orang guru mata pelajaran serta 3 orang observer untuk menilai kepraktisan perangkat pada setiap pertemuan. Uji coba ini digunakan untuk memperoleh masukan langsung berupa respon serta komentar peserta didik sebagai sasaran pengguna model dan modul. Ujicoba juga digunakan untuk memperbaiki produk hingga diperoleh produk yang valid, efektif dan efesien. Pada tahapan ujicoba ini juga dilihat apakah terdapat peningkatan penguasaan konsep setelah diterapkan pembelajaran menggunakan model ao.

Berdasarkan data yang telah diperoleh pada tahap validasi, selanjutnya dilakukan analisis validan RPP, instrumen tes penguasaan konsep serta modul ajar berbantuan advance organizer untuk mengetahui validitas dari perangkat tersebut. Adapun hasil analisis validitas perangkat disajikan dalam tabel 5 .

Tabel 5. Analisis Validitas Perangkat.

\begin{tabular}{ccc}
\hline Perangkat & $\begin{array}{c}\text { Rata-Rata } \\
\text { Nilai }\end{array}$ & Kriteria \\
\hline RPP & $84,72 \%$ & Cukup valid \\
\hline Modul ajar & $82,07 \%$ & Cukup valid \\
\hline $\begin{array}{c}\text { Instrumen } \\
\text { penguasaan } \\
\text { konsep }\end{array}$ & $76,85 \%$ & Cukup valid \\
\hline
\end{tabular}

Berdasarkan data pada tabel 5, perangkat pembelajaran berupa RPP dan instrumen penguasaan konsep telah memenuhi kriteria cukup valid dengan rata-rata nilai $84,72 \%$ serta dapat digunakan dalam pembelajaran. Hal ini sejalan dengan penilitian yang dilakukan oleh Fatmawati (2016) yang memperoleh hasil validitas untuk RPP sebesar $75,00 \%$ dengan kriteria cukup valid. RPP yang telah divaliasi tersebut selanjutnya digunakan dalam kegiatan belajar mengajar tentu setelah dilakukan beberapa perbaikan dan saran dari validator. Seperti pada alokasi waktu yang disediakan, penataan ulang kalimat pada tujuan pembelajaran, dan penambahan instrumen penilaian pada RPP.

Sementara itu, modul ajar berbantuan advance organizer juga dapat digunakan dalam 
pembelajaran dengan hasil validitas 82,07\% yang memenuhi kriteria cukup valid. Nilai validitas modul pada penelitian ini lebih tinggi dibandingkan penelitian sebelumnya yang dilakukan oleh Ernawati (2014) juga mengembangkan modul namun tanpa bantuan ao. validitas modul yang dihasilkan hanya sebesar $81 \%$. Artinya, modul berbantuan ao lebih baik digunakan dalam pembelajaran dibandingkan dengan modul yang tidak berbantuan ao. Hal ini juga diperkuat oleh penelitian yang telah dilakukan oleh Primadani (2017) bahwa kombinasi dari model dan media pembelajaran yang tepat dapat memberikan dampak yang positif terhadap penguasaan konsep serta kemampuan pemecahan masalah peserta didik.

\section{Hasil Validasi Perangkat}

Selanjutnya setelah semua perangkat telah divalidasi kemudian dihitung reabilitasnya. Hasil analisis reliabilitas perangkat pembelajaran dapat dilihat pada Tabel 5.

Tabel 6. Analisis Reabilitas Perangkat.

\begin{tabular}{lcl}
\hline \multicolumn{1}{c}{ Perangkat } & $\begin{array}{c}\text { Rata-Rata } \\
\text { Nilai }\end{array}$ & Kriteria \\
\hline RPP & $94,24 \%$ & Reliabel \\
\hline Modul ajar & $94,93 \%$ & Reliabel \\
\hline $\begin{array}{l}\text { Instrumen } \\
\text { penguasaan } \\
\text { konsep }\end{array}$ & $91,36 \%$ & Reliabel \\
\hline
\end{tabular}

Berdasarkan data pada tabel 6, perangkat serta modul ajar yang dikembangkan memiliki nilai reliabilitas di atas $75 \%$. Hal ini berarti perangkat dikatakan reliabel yang artinya perangkat dapat dipercaya sebagai alat ukur. Hasil reabilitas tersebut didukung oleh penelitian yang dilakukan oleh Nur dkk (2020) diperoleh persentase reliabilitas Silabus $(96,00 \%)$, RPP $(97,74 \%)$, LKS $(96,30 \%)$ dan instrumen tes pengetahuan metakognisi $(97,43 \%)$ dengan kategori reliabel.

Dari penjabaran sebelumnya maka perangkat pembelajaran yang telah dikembangkan dalam penelitian ini memiliki tingkat reliabilitas yang sangat tinggi dan dapat digunakan dalam kegiatan pembelajaran dengan sedikit perbaikan. Adapun keterlaksanaan pembelajaran menggunakan RPP dan modul ajar berbantuan Advance Organizer mencapai $88,89 \%$ atau dapat dikatakan praktis untuk dilaksanakan.

Perangkat kemudian diujicobakan secara terbatas kepada 25 orang peserta didik kelas XI IPA untuk mengetahui peningkatan penguasaan konsep fisika. Secara keseluruhan, rata-rata $\mathrm{N}$-gain seluruh peserta didik adalah 0.43 kriteria sedang, dengan kategori tidak ada peserta didik yang masuk dalam kategori tinggi, 18 peserta didik masuk dalam kategori sedang dan 7 peserta didik masuk dalam kategori rendah. Peningkatan penguasaan konsep melalui uji $\mathrm{N}$-gain dapat dilihat pada Tabel 6 dan Tabel 7 berikut.

Tabel 7. Analisis Rata-rata Penguasaan Konsep melalui Uji N-gain

\begin{tabular}{ccccc}
\multicolumn{5}{c}{ Konsep melalui Uji } \\
\hline $\bar{X}$ Pre & $\bar{X}$ Post & $\bar{X}$ Post & 100 & $N$ \\
& & $-\bar{X}$ Pre & $-\bar{X}$ Pre & - Gain \\
\hline 38,09 & 69,94 & 26,85 & 61,91 & 0,43 \\
\hline
\end{tabular}

Tabel 8. Analisis Kategori Peserta Ddidik melalui Uji N-gain

\begin{tabular}{cccc}
\hline $\begin{array}{c}N-g a i n ~ S c o r e \\
(g)\end{array}$ & Kategori & $\begin{array}{c}\text { Jumlah } \\
\text { Peserta } \\
\text { Didik }\end{array}$ & Presentase \\
\hline $0,70<\mathrm{g}<1,00$ & Tinggi & 0 & $0,00 \%$ \\
$0,30<\mathrm{g}<0,70$ & Sedang & 18 & $72,00 \%$ \\
$0,0<\mathrm{g}<0,30$ & Rendah & 7 & $28,00 \%$ \\
\hline
\end{tabular}

Berdasarkan data yang tersaji pada tabel 7 dan tabel 8, terjadi peningkatan penguasaan konsep fisika peserta didik pada materi suhu dan kalor setelah setelah diterapkan pembelajaran menggunakan modul ajar berbantuan advance organizer. Grafik peningkatan nilai pretest dan posttest peserta didik dapat dilihat pada grafik di bawah ini.

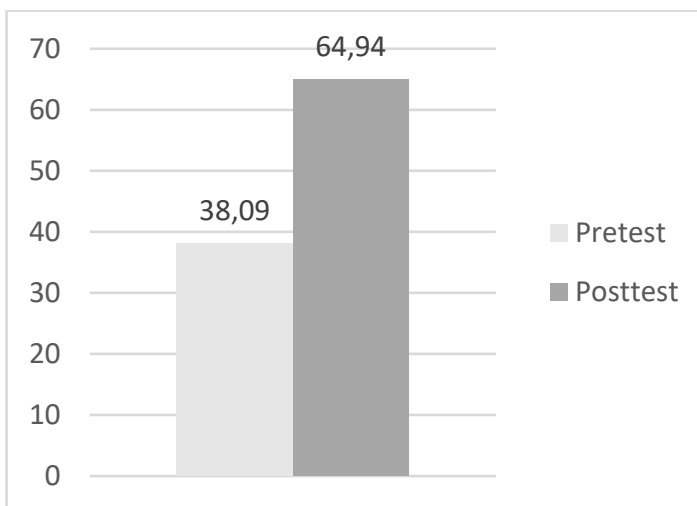

Gambar.1 Grafik Nilai Rata-rata Pretest dan Posttest

Harjono (2012) juga mengungkapkan bahwa pemberian Advance Organizer dapat meningkatkan hasil belajar peserta didik dibandingkan tanpa pemberian Advance Organizer. Hal ini sejalan dengan penelitian yang dilakukan oleh Mika (2014) yang menyatakan bahwa model Advance Organizer dapat meningkatkan hasil belajar peserta didik sehingga dapat menjadi alternative pilihan dalam belajar-mengajar di kelas. Penelitian yang dilakukan oleh Matsun dkk (2020) juga mendukung bahwa pembelajaran menggunakan modul terutama selama masa pandemi ini memberikan dampak yang positif terhadap hasil belajar peserta didik. 
Penilaian terakhir yaitu untuk mengetahui kepraktisan perangkat dan bahan ajar yang dikembangkan, dalam keterlaksaannya selama pembelajaran adalah sebesar $88,89 \%$. Artinya para observer menilai bahwa perangkat dan bahan ajar yang dikembangkan sangat baik serta praktis digunakan dalam pembelajaran. Sejalan dengan Herwati (2013) bahwa penggunaan modul dalam kegiatan belajar sangat penting dalam mendesain pembelajaran sehingga peserta didik akan lebih tertarik dalam belajar yang secara otomatis dapat meningkatkan hasil belajar.

Sementara itu untuk menilai baik tidaknya atau bermakna tidaknya suatu modul ditentukan oleh mudah tidaknya suatu modul digunakan oleh peserta didik dalam kegiatan pembelajaran. Modul ajar ini dilengkapi dengan latihan-latihan soal beserta penyelesainnya untuk memperkuat pemahaman peserta didik. Berdasarkan respon peserta didik terhadap modul yang dikembangkan memiliki rata-rata persentase respon sebesar $79,50 \%$ dengan kategori sangat setuju.

Penelitian sebelumnya yang dilakukan oleh Nisyah (2019) menunjukkan respon peserta didik terhadap perangkat yang dikembangkan berkisar pada $76.00 \%-85.00 \%$ dengan kriteria praktis dan tebaca. Hal ini menunjukkan bahwa pembelajaran dengan modul berbantuan ao dapat diterima dalam pembelajaran. Hal ini juga sejalan dengan penelitian yang dilakukan oleh Jannah dkk (2018) bahwa media pembelajaran menggunakan modul fisika teruji efektifitasnya dan mempunyai pengaruh dalam peningkatan motivasi belajar peserta didik. Dapat disimpulkan bahwa langkah-langkah dalam RPP serta modul ajar berbantuan ao mampu dipahami oleh guru dan peserta didik sehingga dapat diterapkan dalam pembelajaran dengan skala yang lebih luas.

\section{Tahap Penyebarluasan (Disseminate)}

Pada tahap ini dilakukan
penyebarluasan produk yang telah dikembangkan setelah seluruh produk memenuhi kriteri valid, praktis dan efektif. Penyebaran dilakukan dengan cara memperbanyak produk kemudian diberikan kepada peserta didik di sekolah tempat dilakukannya penelitian.

\section{SIMPULAN DAN SARAN}

Berdasarkan hasil penelitian dan pembahasan, maka diperoleh kesimpulan bahwa pengembangan bahan ajar berbantuan advance organizer layak digunakan dalam pembelajaran karena hasil validasi produk memiliki kriteria valid dan reliabel. Selain itu, bahan ajar yang dikembangkan efektif untuk meningkatkan penguasaan konsep peserta didik. Hal ini terbukti dari perolehan skor $\mathrm{N}$-gain terjadi peningkatan penguasaan konsep peserta didik pada materi suhu dan kalor sebesar 0,43 .

Saran untuk penelitian selanjutnya yang sejenis agar penelitian ini dilakukan sampai uji coba skala luas. Penelitian pengembangan seperti ini dapat dilakukan pada konsep lain dengan cangkupan materi yang lebih luas dengan harapan mampu meningkatkan hasil belajar ranah kognitif maupun afektif peserta didik.

\section{UCAPAN TERIMAKASIH}

Ucapan terimakasih sebesar-besarnya penulis ucapkan kepada Universitas Mataram selaku lembaga yang memfasilitasi penelti dalam melakukan penelitian ini, kepada MA Hikmatusysyarif yang telah memberikan kesempatan kepada peneliti untuk melakukan ujicoba terbatas. Terimakasih pula peneliti sampaikan kepada Bapak Wahyudi, S.Si, M.Si., dan I Wayan Gunada, S.Si., M.Pd selaku pembimbing pertama dan kedua yang tetap meluangkan waktunya untuk membimbing penulis dalam melakukan penelitian ini.

\section{DAFTAR RUJUKAN}

Akbar, Sa'adun. (2013). Instumen Perangkat Pembelajaran. Bandung: Rosdakarya.

Aunurrahman. (2009). Belajar dan Pembelajaran. Bandung: Alfabeta.

Borich, G. D. (1994). Observation Skill for Effective Teaching. New York: Macmillan Publishing Company.

Ernawati. (2014). Pengembangan Perangkat Pembelajaran Berdasarkan Model 4-D pada Materi Getaran Gelombang dan Bunyi dalam Meningkatkan Pemahaman Konsep Siswa SMP Negeri 6 Palu. Jurnal Sains dan Teknologi Tadulako, 3 (1): 6271.

Fatmawati, A. (2016). Pengembangan Perangkat Pembelajaran Konsep Pencemaran Lingkungan menggunakan Model Pembelajaran Berdasarkan Masalah untuk SMA Kelas X. EduSains, 4(2), 94-103.

Gunawan, G. (2017). Keterampilan Berpikir Dalam Pembelajaran Sains. Mataram: Arga Puji Press.

Harjono, A. (2012). Perbedaan Strategi Pembelajaran dan Pemberian Advance Organizer Pengaruhnya Terhadap Hasil Belajar Fisika Siswa Kelas X. Jurnal Pijar MIPA, 7(1): 13-17.

Harjono, A., Gunada, I. W., Sutrio. S., \& Hikmawati, H. (2018). Penerapan Advance Organizer dengan Model 
Pembelajaran Ekspositori Berpola Lesson Study Untuk Meningkatkan Hasil Belajar Fisika Peserta Didik. Jurnal Pendidikan Fisika dan Teknologi, 4(1): 141-150.

Herwati, Heni. (2013). Pengembangan Bahan Ajar Modul Kemampuan Kognitif Untuk Orang Tua Taman Kanak-Kanak Usia 45 Tahun di Bandar Lampung. Tesis. Lampung: Pascasarjana FKIP Universitas Lampung.

Hidayat, Wildan., Muhammad Taufik \& Gunawan. (2019). Pengaruh Model Pembelajaran Inquiry Training Berbantuan Multimedia Terhadap Penguasaan Konsep Fisika Peserta Didik. Jurnal Pendidikan Fisika dan Teknologi, 5(1): 1-6.

Jannah, Zulfah Baijatul., Islahudin., Ni Wayan Sri Darmayanti. (2018). Pengembangan Modul Fisika Bilingual Materi Hukum Newton Pada Siswa SMA Kelas X Untuk Meningkatkan Motivasi Belajar Fisika Tahun Ajaran 2017/2018. Jurnal Hasil Kajian, Inovasi, dan Aplikasi Pendidikan Fisika. 4(2): 37-46.

Lestari, Ika. (2013). Pengembangan Bahan Ajar Berbasis Kompetensi. Padang: Academia Permata.

Matsun., Dwi Fajar Saputri. (2020). Pengembangan E-Modul Fisika Berbantuan Whatsapp Sebagai Alternatif Pemebalajaran di Masa Pandemi Covid 19. Jurnal Hasil Kajian, Inovasi, dan Aplikasi Pendidikan Fisika.6(2): 1-8.

Mika, Jahratun., Zainddin, \& Syubhan An'nur. (2014). Penerapan Model Pembelajaran Advance Organizer $(A O)$ untuk Meningkatkan Hasil Belajar Siswa. Berkala Ilmiah Pendidikan Fisika., 2 (3): 222-233.

Nisyah, Mir'atun., Gunawan., Ahmad Harjono \& Mahesti Kusdiastuti. (2019). Perangkat Pembelajaran Model Inkuiri dipadu Advance Organizer untuk Meningkatkan Penguasaan Konsep dan Kemampuan Pemecahan Masalah Fisika Siswa. Jurnal Pijar MIPA, 14(2):1-6.

Nur, A. R., Prayogi S., \& Asyi'ari M. (2020). Validitas Perangkat Pembelajaran Berbasis PBL Dengan Pendekatan Konflik Kognitif Untuk Membelajarkan Kemampuan Metakognisi. Empiriscm jurnal. 1(1): 1-16.

Prastowo, Andi. (2012). Panduan Kreatif Membuat Bahan Ajar Inovatif. Yogjakarta: DIVA Press.

Primadani, R., Tukiran, T., \& Jatmiko, B. (2017). Pengembangan Perangkat
Pembelajaran Fisika Model Structured Inquiry Untuk Meningkatkan Keterampilan Pemecahan Masalah Siswa Pada Materi Fluida Statis. Jurnal Penelitian Pendidikan Sains, 6(1): 12351245.

Sari, P,I., Gunawan, G., \& Harjono. A. (2016). Penggunaan Discovery Learning Berbantuan Laboratorium Virtual Pada Penguasaan Konsep Fisika Siswa. Jurnal Pendidikan Fisika dan Teknologi, 2(4): 176-182.

Setyawati, Heni. (2017). Pengembangan Perangkat Pembelajaran Berbasis Masalah Untuk Meningkatan Keterampilan Proses Sains Siswa. Bioedukasi, XV (1): 32-42.

Sugiyono. (2014). Metode Penelitian Pendidikan: Pendekatan Kuantitatif, Kualitatif, Dan R\&D. Bandung: Alfabeta.

Sundayana, Rostina. (2014). Statistika Penelitian Pendidikan. Bandung: Alfabeta.

Suprijono, Agus. (2016). Cooperative Learning Teori dan Aplikasi Paikem. Yogyakarta: Pustaka Pelajar.

Syamsudin, Makmum. (2005). Psikologi Kependidikan Perangkat System Pengajaran Modul. Bandung: Remadja Rosdakarya. 